Relations industrielles

Industrial Relations

\title{
Quinlan, M., ed., Work and Health
}

\section{Eric Tucker}

Volume 49, numéro 2, 1994

URI : https://id.erudit.org/iderudit/050949ar

DOI : https://doi.org/10.7202/050949ar

Aller au sommaire du numéro

\section{Éditeur(s)}

Département des relations industrielles de l'Université Laval

\section{ISSN}

0034-379X (imprimé)

1703-8138 (numérique)

Découvrir la revue

Citer ce compte rendu

Tucker, E. (1994). Compte rendu de [Quinlan, M., ed., Work and Health]. Relations industrielles / Industrial Relations, 49(2), 416-419.

https://doi.org/10.7202/050949ar

Tous droits réservés (C) Département des relations industrielles de l'Université Laval, 1994
Ce document est protégé par la loi sur le droit d'auteur. L'utilisation des services d'Érudit (y compris la reproduction) est assujettie à sa politique d'utilisation que vous pouvez consulter en ligne.

https://apropos.erudit.org/fr/usagers/politique-dutilisation/ 
légalement reconnu comme représentant exclusif des salariés de l'unité de négociation. Une fois accrédité, le syndicat devra négocier une convention collective avec l'employeur. Ainsi, les auteurs font part des règles qui régissent le déroulement de la négociation collective et des différents modes de règlement des conflits qui peuvent être mis en œuvre au moment de cette négociation. Ils terminent l'étude du Code du travail par un exposé des règles applicables à la convention collective et au règlement des griefs visant son interprétation et son application.

Le onzième chapitre porte sur trois régimes spéciaux du travail. Les auteurs abordent d'abord l'étude du régime général d'extension juridique de la convention collective institué par la Loi sur les décrets de convention collective. Cette loi permet au gouvernement d'étendre par décret, à un secteur d'activités donné et dans une région déterminée, certaines conditions de travail prévies dans une convention collective lorsque la demande lui en est faite par l'une des parties à cette convention. Les auteurs étudient ensuite le régime de relations du travail applicable aux salariés de l'industrie de la construction. Les salariés de ce secteur d'activités sont exclus de l'application du Code $d u$ travail et sont soumis à un régime particulier de négociation collective sectorielle. Les auteurs terminent le onzième chapitre par l'étude du régime des relations du travail applicable aux secteurs public et parapublic. La négociation collective dans ces secteurs d'activités est centralisée à l'échelle provinciale et est régie par des dispositions particulières prévues dans le Code du travail et dans différentes lois spécifiques.

Le douzième chapitre vise les pièces législatives majeures en santé et sécurité du travail. Ainsi sont sommairement étudiées La Loi sur la santé et la sécurité du travail qui a pour objet la prévention des accidents du travail et la Loi sur les accidents du travail et les maladies professionnelles qui institue un régime provincial d'indemnisation des accidents du travail. Le dernier chapitre complète la présentation générale du cadre juridique des relations du travail par l'examen des chartes canadienne et québécoise qui affirment les libertés et les droits fondamentaux de la personne et interdisent l'exercice de mesures discriminatoires.

En somme, le volume Travail Plus répond parfaitement aux buts poursuivis par ses auteurs. Cet ouvrage bien conçu se lit facilement et favorise l'acquisition de connaissances juridiques générales en matière de relations du travail au Québec.

Diane VeilleuX

Université de Montréal

Work and Health, edited by M. QuINLAN, Melbourne, Macmillan Education Australia, 1993, 353 p., ISBN 0-7329-1486-8.

The study of occupational health and safety lends itself to a multi-disciplinary approach. To explore the causes of injury and disease and to design and assess regulatory responses may require the insights of economics, sociology, psychology, political science and law. Most books on occupational health and safety, including edited collections, tend to approach the subject from a single disciplinary perspective; better ones may include two. This fine collection breaks with that tradition. It assembles articles 
written by researchers in the fields of law, criminology, industrial relations, sociology and environmental studies and the result is a rich and fascinating examination of occupational health and safety issues from diverse perspectives.

Almost all the studies reflect on Australian experience, but this does not diminish their value for Canadian or American readers. The regulatory systems of most western industrial capitalist states have undergone reforms in the last two decades which share certain common characteristics. These include: greater emphasis on health hazards including exposures to toxic substances, some recognition of worker rights to know, participate and refuse unsafe work, and tougher sanctions. Also, similar problems confront these systems including law-breaking by powerful corporations, the transformation of work and work organization, and issues arising out of the entry of women into new areas of work. As a result, readers will find that the problems being addressed, and the context in which they arise, are familiar to them.

The introductory essay by Michael Quinlan and Richard Johnstone nicely frames the issues raised by the contributors. They provide a good overview of four prevalent theorizations of the relation between work and health, highlighting how each emphasizes different sources of worker ill health. While as a general matter the authors wish to encourage researchers to be more conscious of their frame of reference and to broaden their horizons, they also want to emphasize the importance of the industrial relations context and the need to examine processes of control, consensus and conflict inherent in the employment relationship. Indeed, if there is any common thread which links the various contributors, it is that their work is informed by this premise. Few, if any, treat health and safety merely as a technical problem.

Quinlan and Johnstone also point to the broad range of regulatory instruments and infrastructures which potentially impact on health and safety. Common law, statutes, regulations and codes of practice are overseen by judges and an array of administrative and enforcement bureaucracies. In short, the state is institutionally complex and studies must be sensitive to the dynamics of the particular setting and aware of the interactions between different components of the total regulatory regime.

In the space of a short review, it is impossible to deal with all the themes, let alone all the essays, in this book. A few have been selected because of their particular relevance for Canadian readers.

Workers' compensation systems are always a source of complaint and controversy in Canada and, it seems, in Australia. Christopher Arup argues that the complexity of the debates stems from the fact that more is at stake than just the conferral of benefits. There are contradictory pressures on the system coming from different groups with conflicting agendas. Demands are made that workers' compensation should compensate adequately, provide social security, operate economically, promote economic efficiency, deter or prevent injury, rehabilitate injured workers, etc. While Arup does not provide solutions to the problems that beset the system, his examination of various perspectives on the compensation debate will help readers to understand and critically scrutinize some of the positions being advocated in Canada. A second essay, by Claire James, examines the phenomenon of non-reporting of work-related accidents and illnesses. Studies in the United Kingdom and Manitoba have estimated that there may be 
as many as three times more compensable accidents than are reported. While James finds a lower incidence of non-reporting (about $25 \%$ ), she also explores the social processes which influence reporting or non-reporting. Her finding that labour market insecurity reduces the likelihood of an injury being reported should be of particular concern in light of the restructuring of the Canadian labour market which is producing more precarious employment. As in other areas, it seems laws designed for men employed full time in heavy industry need to be re-examined if they are going to respond to the realities of the current workforce.

The relation between gender, precarious employment and health and safety at work is taken up by Claire Williams in her study of blue collar workers in the South Australian timber industry. She argues that it is important to attend to the differences in men's and women's work lives and to understand how these differences impact on their health and safety at work. The social construction of male working-class identities around danger and risk-taking is itself conditioned by the hazardous conditions to which they are exposed. Ironically, the normalization, or even celebration, of male risk-taking helps to perpetuate the conditions which foster this attitude. Labour market segregation has resulted in women being disproportionately located in low-skill, low-control, casual and part-time jobs. This, in addition to the heavy domestic responsibilities most working women bear and the problem of sexual harassment at work, adversely impacts on women's health. The salience of this discussion for Canada was recently underlined in study by Statistics Canada which found that the percentage of women injured badly enough to lose time from work has increased more than twice as fast as the percentage of female workers. Much of this was attributed to a rise in the number of back, shoulder and hand injuries related to stress and repetitive movements.

Another theme raised by the essays is the separation of health and safety regulation from industrial relations. This separation has a long history, dating to at least the earliest factory acts which made minimum occupational health and safety standards a matter of public concern rather than private negotiation, and is rooted in the contradiction which lies at the core of capitalist relations of production between labour as a subject and labour power as an object. Because the killing and injuring of workers makes this contradiction both obvious and unacceptable, the problem has been externalized; that is, despite its obvious centrality to the employment relationship, health and safety is often not considered a matter for industrial relations. The completeness of this separation, and its effects, are contentious matters. Quinlan emphasizes the negative effects of this separation and is hopeful that legislation giving workers greater voice in health and safety matters will yield positive results. There are, however, arguably some benefits from this separation. One effect of externalizing health and safety is that it is formally de-commodified. Workers can claim they have a right to safe and healthy workplaces because they are citizens, not because they are sellers of a commodity. Indeed, it is because of the special status of health and safety claims that workers have been able to obtain rights to know, participate and refuse, rights which they do not enjoy in the internal industrial relations system. The re-integration of health and safety with industrial relations through schemes which require the workplace parties to partially self-regulate creates both opportunities and dangers. In particular, during a period in which the leverage of employers is increasing, there are good reasons to fear that re-integration will 
leave many workers worse off and will have especially serious consequences for the most vulnerable.

Of course, one reason why the creation of internal responsibility systems is viewed favourably is that external responsibility systems failed to generate adequate standards and, more importantly, to enforce them. The question of when and how to punish employers who violate standards has been a controversial one, both here and abroad. Andrew Hopkins makes a useful distinction between preventive and reactive responses. Occupational health and safety regulations aim to minimize risk. Most violations of those laws do not cause actual harm, but increase the risk of harm occurring and should be penalized accordingly. Where harm does materialize, then a reactive approach, like that embodied in the criminal law, should be applied. By thinking more clearly about what it is being sanctioned, we can make better decisions about the most appropriate means. It is not enough, however, to advocate the use of criminal law in appropriate cases. We need to understand why there is such resistance to the use of this mechanism. This question is taken up by Polk et al. They find that, despite changes to the law in 1985 which aimed to increase the frequency and seriousness of prosecution for health and safety violations, there has been little resort to the criminal law. The reasons for this include the relatively infrequent occurrence of conduct warranting criminal sanction and organizational complexity which diffuses blame. The authors suggest that a special statute dealing with health and safety crime might provide a way around some of the constraints which inhibit the use of criminal law. This suggestion received some support in Canada, but has never been acted upon. There are clearly problems with it, as the authors recognize, but the need to re-think our approach to punishment is becoming more apparent and urgent in light of the ongoing effort to prosecute the Curragh Resources Inc. and two of its managerial employees for the death of 26 miners in the Westray disaster.

There are many other fine essays not touched upon here, including ones by Richard Johnstone on pre-employment health screening and by Breen Creighton on the role of ILO standards. The collection is a valuable addition to the literature and provides a good introduction to a broad range of health and safety research.

Eric TUCKer

York University 